\title{
Study of the growth of three species: Micropterus salmoides(Lacépède, 1802), Cyprinus carpio (Linneaus, 1758) and Oreochromis niloticus (Linnaeus, 1758) in Moroccan continental waters
}

\author{
Loubna FERRAJ $^{1 *}$, Meriem BOUSSEBA ${ }^{1}$, Sara OUAHB $^{1}$, Aziz EL MOUJTAHID ${ }^{1}$, and Mustapha HASNAOUI ${ }^{1}$ \\ ${ }^{1}$ Environmental Engineering Team,Sciences and Techniques Faculty, Sultan MoulaySlimane University,Beni-Mellal, Morocco \\ *Email: ferraj01.loubna@gmail.com
}

\begin{abstract}
The growth parameters of three species were studied for the first time in the AlMassira Dam. A total of 137 individuals were examined during this study between September 2020 and January 2021. The estimation of growth parameters was carried out by size structure analysis using FISAT II software. The growth parameters of Micropterus salmoides, Cyprinus carpio and Oreochromis niloticus are respectively: $\boldsymbol{L} \infty=35.11 \mathrm{~cm}, \mathrm{~K}=0.58$ year $^{-1}, \mathrm{t}_{0}=0.57$ year; $\boldsymbol{L} \infty=44.85 \mathrm{~cm}, \mathrm{~K}=2.60$ year $^{-1}, \mathrm{t}_{0}=1.27$ year and $\boldsymbol{L} \infty=45.26 \mathrm{~cm}, \mathrm{~K}=0.32$ year $^{-1}, \mathrm{t}_{0}=0.33$ year. Thus, the Von Bertalanffy growth equations are written respectively: $L(t)=35.11\left(1-e^{-0.58}\right.$ $\left(\boldsymbol{t}^{+0.57)}\right), \mathrm{L}(\mathrm{t})=44.85\left(1-\boldsymbol{e}^{-2.60\left(\boldsymbol{t}^{+1.27)}\right)}\right.$ and $\mathrm{L}(\mathrm{t})=45.26\left(1-\boldsymbol{e}^{-0.32\left(\boldsymbol{t}^{+0.33)}\right)}\right.$.
\end{abstract}

Keywords: Al-Massira Dam, Micropterus salmoides, Cyprinus carpio, Oreochromis niloticus, Growth.

\section{Introduction}

Growth refers metabolically to the amount of energy used to increase body weight and length[1,2]. Growth studies have often been used to analyse the structure and dynamics of fish populations. Similarly, in fisheries ecology, growth is an indicator of fish habitat quality [3].

Growth processes in fish are conditioned by habitat quality[4,5,6]. Similarly, several other factors can influence fish growth: seasons[5], age and physiological condition[2], and sex[6].

Indeed, studies on the ichthyofauna of freshwater in Morocco have not been pervasive and have generally been limited to the systematic side, except for a few works[9,10,11,12,13]. Studies concerning the ecology and biology of fishes in rivers and reservoirs are few. For a long time, studies have been carried out on the determination and knowledge of the traits of fish populations in different aquatic environments. Among the characteristics generally studied are size, growth, size-weight relationship, age and others.

In this context, this work is about the study of some parameters of the growth of three species of the Al-Massira Dam which are: Micropterus salmoides, Cyprinus carpio and Oreochromis niloticus, to ensure sustainable exploitation of these species.

\section{Materials and Methods}

The Al-Massira Dam is located on the main course of the Oued Oum Erbia, $70 \mathrm{~km}$ south of Settat. The climate of the reservoir area is of semiarid to arid Mediterranean type. It is characterised by hard waters (total hardness in the epilimnion varies from $127 \mathrm{mg} / \mathrm{l}$ to $367 \mathrm{mg} / \mathrm{l}$ and $\mathrm{Ca} 2+$ from 24 $\mathrm{mg} / \mathrm{l}$ to $78 \mathrm{mg} / \mathrm{l}$ ) and an alkaline $\mathrm{pH}$ between 8 and 9[8]. Thus, the reservoir is classified as an oligotrophic to mesotrophic system. The Al Massira Reservoir is one of the largest Moroccan reservoirs, with multiple uses: drinking water, agriculture, industry and energy.

The fish examined were collected monthly between September 2020 and January 2021. The three species (black bass, common carp and tilapia) come from the Al-Massira Dam. On each specimen, the total length (TL) was determined using an ichthyometer.

The analysis of the growth parameters of the three species was carried out based on sizefrequency data of 124 specimens ranging in size from 17.5 to $34 \mathrm{~cm}$ for black bass, 14.5 to $43 \mathrm{~cm}$ for common carp and 10.5 to $43 \mathrm{~cm}$ for tilapia. Programmes incorporated in the FISAT II software[9] were used for this analysis.

\subsection{Determination of growth parameters}

The study of growth was determined using the Von Bertalanffy model [16], whose equation is: 


$$
L t=L \infty\left(1-e^{K(t-t)}\right)(1)
$$

With: $\mathrm{Lt}=$ length of the fish at time $\mathrm{t}$ considered (cm); $\boldsymbol{L} \infty=$ asymptotic length (cm), it is the length that the species could reach if it continues to live and grow infinitely; $\mathrm{K}=$ the growth coefficient characterising the speed with which the species grows towards $\boldsymbol{L} \propto$ (year-1); $\mathrm{t}_{0}=$ theoretical age of the fish when its size is zero (year).

\subsubsection{Asymptotic length $L_{\infty}$}

The asymptotic length $L \infty$ is interpreted as the average length of very or infinitely aged fish[10]. The estimation of this parameter is done by different methods:

\section{- Pauly's method[11]:}

In this method, L $\infty$ depends on the size of the largest fish measured in the Lmax sample:

$$
\boldsymbol{L} \infty=\operatorname{Lmax} / \boldsymbol{0 . 9 5}(2)
$$

\section{- $\quad$ ELEFAN I method[12]:}

The ELEFAN (Electronic Lenght Frequency Analysis) method was first proposed by[12] and modified by[20, 17,21, 22]. The most recent description can be found in[14].This method estimates growth parameters by length-frequency analysis. It increases the objectivity and reliability of the growth curves obtained.

- $\quad$ Powell's method[15]-Wetherall's method [16]:

This method is a particular application of Von Bertalanffy's equation[17], allowing the determination of the parameter $\mathrm{L} \infty$ and the $\mathrm{Z} / \mathrm{K}$ ratio from the following linear equation:

$$
L m-L^{\prime}=a+b L^{\prime}
$$

Where: $\mathrm{Lm}=$ the average length $(\mathrm{cm})$, calculated from $L^{\prime}, L^{\prime}=$ the lower limit of each size class $(\mathrm{cm})$, $a=$ original ordinate, $b=$ slope of the regression line.

The results are cumulated from the bottom to the top of the size-frequency distribution.

$$
L \infty=-a / b Z / K=-(1+b) / b(4)
$$

Where: $\mathrm{K}=$ the coefficient of catabolism, $\mathrm{Z}=$ the total mortality rate.

\subsubsection{The catabolism coefficient $K$}

According to[14], the catabolism coefficient $\mathrm{K}$ is the curvature parameter that determines how fast the fish will reach $L \infty$. It is also the stress coefficient, which is estimated based on comparative studies of the growth of the species studied. Pauly and Munro [18] use the following relationship:

$$
\boldsymbol{\Phi}^{\prime} m=\log 10(\boldsymbol{K})+2 \log _{10}(\boldsymbol{L} \infty)(5)
$$

Where: $\oint$ 'm $=$ average growth rate.

The growth parameter $\mathrm{K}$ in a defined stock is deducted from the following formula:

$$
\boldsymbol{K}=10\left(\boldsymbol{\Phi}^{\prime}-2 \log _{10}(\boldsymbol{L} \infty)\right)(6)
$$

\subsubsection{Hypothetical age $t_{0}$}

The hypothetical age, or the initial condition parameter, $\mathrm{t}_{0}$, determines the time point or the fish at length zero. The determination of this parameter is done by the relation of Pauly (1980)[19]:

$$
\begin{gathered}
\log _{10}\left(t_{0}\right)=-0,3922-0,2752 \times \operatorname{lo}_{10}(L \infty)-1, \\
038 \times \log _{10}(K)(7)
\end{gathered}
$$

\section{Results}

\subsection{Estimation of the asymptotic size $L \infty$}

The values of the asymptotic lengths $\boldsymbol{L} \infty$ obtained for the three species (Black bass, carp and tilapia) by the Pauly method[11]are overall greater than that of the maximum sizes observed (Table 1).

Table 1. Asymptotic length estimated by the Pauly method.

\begin{tabular}{|l|c|c|c|}
\hline Species & $\begin{array}{c}\text { Micropterus } \\
\text { salmoides }\end{array}$ & $\begin{array}{c}\text { Cyprinus } \\
\text { carpio }\end{array}$ & $\begin{array}{c}\text { Oreochromis } \\
\text { niloticus }\end{array}$ \\
\hline $\mathbf{L m a x}(\mathrm{cm})$ & 34 & 34 & 43 \\
\hline $\boldsymbol{L} \infty(\mathrm{cm})$ & 35.79 & 35.79 & 45.26 \\
\hline
\end{tabular}

The analysis of the size-frequency distributions

\begin{tabular}{|c|c|c|c|}
\hline Species & $\begin{array}{c}\text { Micropterus } \\
\text { salmoides }\end{array}$ & $\begin{array}{c}\text { Cyprinus } \\
\text { Carpio }\end{array}$ & $\begin{array}{c}\text { Oreochromis } \\
\text { niloticus }\end{array}$ \\
\hline $\mathrm{L} \infty$ & 35.18 & 44.63 & 47.78 \\
\hline
\end{tabular}
processed by the ELEFAN I program of the FiSAT II software allows an automatic search for the values of $\mathrm{L} \infty$ (Figure 1).

Table 2 summarizes the values obtained by the K Scan tab.

Table 2. Asymptotic length estimated by the ELEFAN method. 

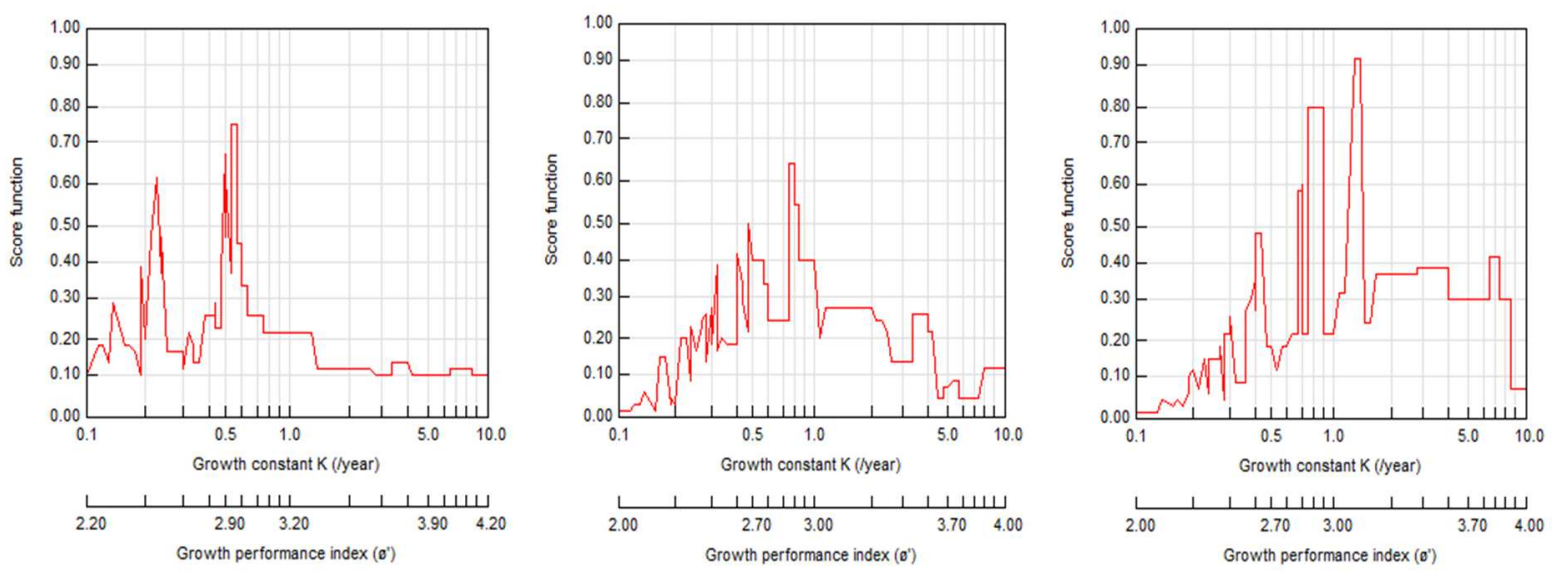

Fig 1. Estimation of L $\infty$ by the ELEFAN I method for common carp (A), black bass (B) and tilapia (C).

The values obtained for $L \infty$ for black bass, common carp and tilapia by Powell -Wetherall method [24,25] are respectively equal to $35.13 \mathrm{~cm}$, $44.85 \mathrm{~cm}$ and $45.26 \mathrm{~cm}$.

\subsection{Coefficient of catabolism $K$ and hypothetical age $t_{0}$}

The different values of $\varphi$ 'obtained by the different authors in various regions and allowing the estimation of $\varphi^{\prime} m$ for the three species are reported in Table 3. The $\varphi$ 'm obtained from these results is 2.86 for black bass, 5.60 for common carp and 2.82 for tilapia. Thus, the values of the specific growth rate $(\mathrm{K})$ and $\mathrm{t}_{0}$ are respectively 0.58 year $^{-1}$ and -0.57 year for the black bass, 2.60 years $^{-1}$ and 1.27 years for the common carp. For tilapia, the values of $\mathrm{K}$ and $\mathrm{t}_{0}$ are respectively 0.32 year $^{-1}$ and 0.33 year.

Table 3 represents the Von Bertalanffy equations[28] for the three species obtained from the growth parameters $\mathrm{L} \infty, \mathrm{K}$ and $\mathrm{t}_{0}$ calculated during this study.

Table 3. Growth equations from Von Bertalanffy.

\begin{tabular}{|l|l|}
\hline Species & Von Bertalanffy's equation \\
\hline $\begin{array}{l}\text { Micropterus } \\
\text { salmoides }\end{array}$ & $\mathrm{L}(\mathrm{t})=35.11\left(1-\boldsymbol{e}^{-0.58\left(\boldsymbol{t}^{+0.57)}\right)}\right.$ \\
\hline $\begin{array}{l}\text { Cyprinus carpio } \\
\text { Oreochromis } \\
\text { niloticus }\end{array}$ & $\mathrm{L}(\mathrm{t})=44.85\left(1-\boldsymbol{e}^{-2.60\left(\boldsymbol{t}^{+1.27)}\right)}\right.$ \\
\hline
\end{tabular}

\section{Discussion}

The linear growth of the three species: black bass, common carp and tilapia from Al-Massira Dam, was studied through the modal progression method based on size-frequency data.[28]model for linear growth was applied for all three species. This model remains, because of its flexibility, the most widely used in estimating linear growth.

Table 3 compares the parameters of the Von Bertalanffy equation [28] and the growth performance index $(\varphi)$ in black bass, common carp and tilapia in different geographic regions. Thus, the performance index valuesare almost for all the species studied except for small differences, which are slight.

The asymptotic length $L \infty$ valueswere found during this study for the different three species from region to region with few exceptions. Indeed, this value is close to that found by[29] and[30] for black bass and that found by[31]for common carp. For tilapia, $L \infty$ is close to that revealed by the work of[32] and[33].

As for the catabolism coefficient $\mathrm{K}$, it represents the highest value compared to that found by other authors in common carp [34,35,36,37] and black bass[38,29,30,39,40]. In tilapia, the value of $\mathrm{K}$ is close to that found by[41], higher than that obtained by[42] and [33] and lower than that obtained by $[43,44,32]$.

The hypothetical age values $t_{0}$ from the many studies carried out in different regions by different authors seem $t_{o}$ be different from those we found for the three species. Only the results obtained by [44]in Ethiopia are close in the tilapia species.

The difference between the different values of the growth parameters of the different authors is explained by the fact that the growth parameters can vary from one stock to another within the same species, that is to say that the growth parameters of a given species can have different values depending on the areas of its distribution. Likewise, successive cohorts can develop differently depending on 
environmental conditions[16], especially temperature. According to[45], temperature plays a signicant role because it acts not only on the production of available food but also on the physiology of individuals. According to [46], the temperature is the most critical factor limiting the growth of fish.

Table 3. Growth parameters of black bass, common carp and tilapia in different regions.

\begin{tabular}{|c|c|c|c|c|c|c|}
\hline Species & $\begin{array}{c}\text { Geographic } \\
\text { area }\end{array}$ & $\begin{array}{c}\text { L } \infty \\
(\mathbf{c m})\end{array}$ & $\mathbf{K}$ & $\mathbf{t}_{\mathbf{0}}$ & $\boldsymbol{\varphi}^{\prime}$ & Reference \\
\hline \multirow{4}{*}{$\begin{array}{c}\text { Micropterus } \\
\text { salmoides }\end{array}$} & North America & 52.9 & 0.15 & -0.024 & & Beamesderfer and al. (1995) \\
\cline { 2 - 7 } & Italy & 51.0 & 0.282 & -0.13 & 2.87 & Lorenzoni and al. (1996) \\
\cline { 2 - 7 } & Japan & 34.1 & 0.498 & -0.07 & 2.76 & Froese and Pauly (1998) \\
\cline { 2 - 7 } & Kenya & 50.8 & 0.46 & -0.01 & 3.07 & Britton and Harper (2005) \\
\cline { 2 - 7 } & South Africa & 42.0 & 0.33 & -0.22 & 2.77 & Taylor and al. (2017) \\
\cline { 2 - 7 } & Morocco & 35.13 & 0.58 & -0.57 & 2.86 & This study \\
\hline \multirow{4}{*}{\begin{tabular}{l} 
Cyprinus carpio \\
\cline { 2 - 7 }
\end{tabular}} & Turkey & 54.53 & 0.140 & -0.753 & 6.03 & Cengizler and Erdem (1989) \\
\cline { 2 - 7 } & Turkey & 72.76 & 0.172 & -0.446 & 6.82 & Alp and Balik (2000) \\
\cline { 2 - 7 } & Turkey & 46.39 & 0.153 & $-1,922$ & 5.80 & Karatas and al. (2007) \\
\cline { 2 - 7 } & Algeria & 36.75 & 0.46 & -0.33 & & Lotfi and Talet (2019) \\
\cline { 2 - 7 } & Kenya & 73.5 & 1.05 & & 3.72 & Mutethya and al.(2020) \\
\hline \multirow{4}{*}{$\begin{array}{c}\text { Morocco } \\
\text { niloticus }\end{array}$} & 44.85 & 2.60 & -1.27 & 5.60 & This study \\
\cline { 2 - 7 } & Kenya & 64.6 & 0.25 & & 3.00 & Getabu (1992) \\
\cline { 2 - 7 } & Bangladesh & 55.6 & 0.39 & & 3.08 & Ahmed and al. (2003) \\
\cline { 2 - 7 } & Ethiopia & 28.1 & 0.43 & & 2.53 & Tesfaye (2006) \\
\cline { 2 - 7 } & Mexico & 17.88 & 0.3409 & -1.543 & & Gómez-Márquez and al. \\
\cline { 2 - 7 } & Ethiopia & 44.5 & 0.41 & -0.36 & 2.90 & Tesfaye and Wolff (2015) \\
\cline { 2 - 7 } & Ethiopia & 45.1 & 0.21 & -0.514 & 2.63 & Degsera and al. (2020) \\
\cline { 2 - 6 } & Morocco & 45.26 & 0.32 & -0.33 & 2.82 & This study \\
\hline
\end{tabular}

\section{Conclusion}

This study clarified the knowledge of the growth of three fish populations (Micropterus salmoides, Cyprinus carpio and Oreochromis niloticus) in particular in the Al-Massira Dam reservoir. Thus, the results show a good growth of these populations with reference to other studies in other geographical areas. Further studies need to be carried out over more extended periods for a good understanding of the biology of these species, to arrive at more conclusive results for the proper management of fisheries resources.

\section{References}

[1] C. Jørgensen and Ø. Fiksen, Statedependent energy allocation in cod (Gadus morhua), Can. J. Fish. Aquat. Sci., vol. 63, no. 1, pp. 186-199, (2006).

[2] C. Lévêque, Les poissons des eaux continentales africaines: diversité, écologie, utilisation par l'homme. IRD Editions, (2006).

[3] S. P. Searcy, D. B. Eggleston, and J. A. Hare, Is growth a reliable indicator of habitat quality and essential fish habitat for a juvenile estuarine fish?, Can. J. Fish. Aquat. Sci., vol. 64, no. 4, pp. 681-691, (2007).

[4] R. Amara, T. Méziane, C. Gilliers, G. Hermel, and P. Laffargue, Growth and condition indices in juvenile sole Solea solea measured to assess the quality of essential fish habitat, Mar. Ecol. Prog. Ser., vol. 351, pp. 201-208, (2007).

[5] I. I. Toko, E. Y. Attakpa, and H. Elegbe, Performances biologiques, zootechniques et nutritionnelles de Tilapia guineensis en milieux naturel et d'élevage, Int. J. Biol. Chem. Sci., vol. 4, no. $5,(2010)$,

[6] F. Kapute, J. Valeta, J. Likongwe, J. Kang'ombe, J. Nagoli, and D. Mbamba, Growth performance of three tilapia fish species raised at varied pond sizes and water depths," Int. J. Fish. Aquac., vol. 8, no. 8, pp. 81-86,(2016).

[7] G. N. Aliko, S. K. Dacosta, A. Outtara, F. K. Konan, and G. Gourene, Structure Demographique D'un Labeo Africain, Labeo coubie Rüppel, 1832 (Pisces: Cyprinidae), Dans Le Lac De Barrage De Taabo (Bassin Du Bandama, 
Côte D'ivoire), Agron. Afr., vol. 22, no. 3, pp. 207-216, (2010).

[8] I. Ilieş, RF. Sîrbulescu , GR. Zupanc: Indeterminate body growth and lack of gonadal decline in the brown ghost knifefish (Apteronotus leptorhynchus), an organism exhibiting negligible brain senescence. Can. J. Zool., vol.92, no.11, pp. 947-953, (2014).

[9] M. Mouslih, Introduction de poissons et d'écrevisses au Maroc, Rev. Hydrobiol. Trop., vol.20, no.1, pp. 65-72, (1987).

[10] C. Almaça, Sur les barbeaux (genre et sous-genre Barbus) de l'Afrique du Nord. Bull. Mus. natl. Hist. nat. Paris, 2e sér., vol. 42, no. 1, pp. 141-158, (1970).

[11] M.R. Sabatié, Recherches sur l'écologie et la biologie des aloses au Maroc (Alosa Alosa Linne, 1758 et Alosa Fallax Lacépède, 1803) : exploitation et taxinomie des populations atlantiques: bioécologie des aloses de l'Oued Sebou, Thèse de Doctorat, Brest, (1993).

[12] S. El Gharbi, Biosystématique, évolution et biogéographie dans les interactions hôte-parasite le modèle Barbus (Cyprinidés) Dactylogyrus (Monogenea), Fac. Sci. Rabat Maroc, 169 p, (1994).

[13] A. Azeroual, A. J. Crivelli, A. Yahyaoui, and M. Dakki, L'ichtyofaune des eaux continentales du Maroc, Cybium, vol. 23, no. 3, pp. 17-22, (2000).

[14] S. Kemmou, J. E. Dafir, M. Taoufik, L. Loukili, M. El Wartiti, and I. Kacimi, Évolution temporelle des éléments nutritifs dans la masse d'eau de la retenue Al Massira (Oum RabiaaMaroc), J Rech Océan., vol. 28, pp. 170-176, (2003)

[15] F. C. Gayanilo, P. Sparre, and D. Pauly, FAO-ICLARM stock assessment tools II: User's guide. Food \& Agriculture Org., (2005).

[16] P. Sparre and S. C. Venema, Introduction à l'évaluation des stocks de poissons tropicaux: Manuel. Food \& Agriculture Org., (1996).

[17] D. Pauly, Quelques méthodes simples pour l'estimation des stocks de poissons tropicaux, FAO Doc Tech Pêch., vol. 234, p. 56 p, (1985).

[18] D. Pauly and N. David, ELEFAN I, a BASIC program for the objective extraction of growth parameters from length-frequency data,
Meeresforschung, vol. 28, no. 4, pp. 205-211, (1981).

[19] D. Pauly, On the interrelationships between natural mortality, growth parameters, and mean environmental temperature in 175 fish stocks, ICES J. Mar. Sci., vol. 39, no. 2, pp. 175192,(1980).

[20] S. E. Sims, Selected Computer Programs in FORTRAN for Fish Stock Assessment. Food \& Agriculture Org., (1985).

[21] D. Thiam, Some improvements and corrections to Sims' version of ELEFAN I, Fishbyte, vol. 4, no. 3, pp. 6-10, (1986).

[22] D. Pauly, A review of the ELEFAN system for analysis of length-frequency data in fish and aquatic invertebrates, in ICLARM conf. Proc, vol. 13, no. 232, pp. 7-34, (1987).

[23] D. Pauly, Méthode pour l'évaluation des ressources halieutiques.(adaptation française: J. Moreau), Cépaduès Éditions Toulouse Fr. 288pp, (1997).

[24] D.G. Powell, Estimation of mortality and growth parameters from the length frequency of a catch. Rapp.P.-V.Réun.Cons.Int.Explor.Mer, vol. 175, pp. 169, (1979).

[25] J. A. Wetherall, A new method for estimating growth and mortality parameters from length frequency data, Fishbyte, vol. 4, no. 1, pp. 12-14, (1986).

[26] Bertalanffy, L. von, Untersuchungen bier die Gesetzlichkeiten des Wachstums I. Rod. Arch. Entwicklungsmech. vol.131, pp. 613-652, (1934).

[27] D. Pauly and J. L. Munro, Once more on the comparison of growth in fish and invertebrates, Fishbyte, vol. 2, no. 1, pp. 1-21, (1984).

[28] L. Von Bertalanffy, A quantitative theory of organic growth (inquiries on growth laws. II), Hum. Biol., vol. 10, no. 2, pp. 181-213, (1938).

[29] Froese, R., and Pauly, D. (ed.),FishBase 98: Concepts, Design and Data Sources. ICLARM, Manila. 293 pp, (1998).

[30] J. R. Britton and D. M. Harper, Preliminary investigations into the age and growth of a largemouth bass population in an equatorial lake. Journal of East African Natural History, vol. 94, no. 2, pp. 363-369, (2005).

[31] M. Karatas, E. Çicek, A. Basusta, and N. Basusta, Age, growth and mortality of common 
carp (Cyprinus carpio Linneaus, 1758) population in Almus Dam Lake (Tokat-Turkey), J. Appl. Biol. Sci., vol. 1, no. 3, pp. 81-85, (2007).

[32] G. Tesfaye and M. Wolff, Stock assessment of fishery target species in Lake Koka, Ethiopia,"Rev. Biol. Trop., vol. 63, no. 3, pp. 755770, (2015).

[33] A. Degsera, M. Minwyelet, and T. Yosef, Age and growth of Nile tilapia Oreochromis niloticus (Linnaeus, 1758) from Lake Tana, Ethiopia, Afr. J. Aquat. Sci., vol. 45, no. 4, pp. 509-519,(2020).

[34] İ. Cengizler and Ü. Erdem, Investigations on the Some Biological Characters of the Population of Common Carp (Cyprinus carpio L., 1758) in Hafik (Sivas) Lake, Doğa TU Zooloji D, vol. 13, no. 3, pp. 175-188, (1989).

[35] A. Alp and S. Balik, Growth conditions and stock analysis of the carp (Cyprinus carpio, Linnaeus 1758) population in Gölhisar Lake, Turk. J. Zool., vol. 24, no. 3, pp. 291-304, (2000).

[36] B. T. Lotfi and A. B. Talet, Age, Growth and Mortality of the Common Carp (Cyprinus carpio) Population in Merdja Sidi Abed Dam, Algeria., Omni-Akuatika, vol. 15, no. 1, pp. 39-46, (2019).

[37] E. Mutethya, E. Yongo, C. Laurent, E. Waithaka, and E. Lomodei, Aspects of the Population biology of Common Carp, Cyprinus carpio (Linnaeus, 1758) In Lake Naivasha, Kenya, https://doi.org/10.31219/osf.io/2kn5h, (2020).

[38] M. Lorenzoni, A. Carosi, A. J. M. DoÈrr, G. Giovinazzo, M. L. Petesse, and M. Mearelli, Accrescimento di Micropterus salmoides (Lacépède) nel lago Trasimeno e nell'invaso di Montedoglio [Growth of Micropterus salmoides (Lacépède) in the Trasimeno Lake and in the Montedoglio reservoir], Atti VI Convegno Aiiad, pp. 177-188, (1996).

[39] R. C. Beamesderfer and J. A. North, Growth, natural mortality, and predicted response to fishing for largemouth bass and smallmouth bass populations in North America, North Am. J. Fish. Manag., vol. 15, no. 3, pp. 688-704, (1995).

[40] G. C. Taylor and O. L. F. Weyl, Age, growth and reproduction of non-native largemouth bass Micropterus salmoides (Lacépède, 1802) populations in two temperate African impoundments, J. Appl. Ichthyol., vol. 33, no. 4, pp. 767-775, (2017).
[41] J. L. Gómez-Márquez, B. Peña-Mendoza, I. H. Salgado-Ugarte, and J. L. ArredondoFigueroa, Age and growth of the tilapia, Oreochromis niloticus (Perciformes: Cichlidae) from a tropical shallow lake in Mexico, Rev. Biol. Trop., vol. 56, no. 2, pp. 875-884, (2008).

[42] A. Getabu, Growth parameters and total mortality in Oreochromis niloticus (Linnaeus) from Nyanza Gulf, Lake Victoria, Hydrobiologia, vol. 232, no. 1, pp. 91-97, (1992).

[43] K. K. U. Ahmed, S. M. N. Amin, G. C. Haldar, and S. Dewan, Population dynamics and stock assessment of Oreochromis niloticus (Linnaeus) in the Kaptai Reservoir, Bangladesh, Indian J. Fish., vol. 50, no. 1, pp. 47-52, (2003).

[44] G. Tesfaye, Population dynamics and stock assessment of Nile tilapia (Oreochromis niloticus L.) in three Rift Valley Lakes (Koka, Ziway and Langano), Ethiopia, Univ. Brem. ZMT Brem. Ger., (2006).

[45] M. Fritsch, Traits biologiques et exploitation du bar commun Dicentrarchus labrax (L.) dans les pêcheries françaises de la Manche et du golfe de Gascogne, Thèse de Doctorat, Université de Bretagne Occidentale, 314 p, (2005).

[46] R. P. King and L. Etim, Reproduction, growth, mortality and yield of Tilapia mariae Boulenger 1899 (Cichlidae) in a Nigerian rainforest wetland stream, J. Appl. Ichthyol., vol. 20, no. 6, pp. 502-510, (2004). 